\title{
DEBATES
}

\section{A direita espanhola dividida: posições ideológicas e clivagem territorial}

\author{
The Spanish right divided: ideological positions and territorial \\ cleavage
}

\author{
Fabio García Lupato \\ Leticia M. Ruiz Rodríguez \\ Gema Sánchez Medero
}

\section{Resumo}

Entre as diferentes mudanças que têm tido lugar no sistema de partidos espanhol, o presente artigo se foca no fim da hegemonia de um único partido no âmbito da direita. É necessária uma análise cuidadosa da distribuição do eleitorado de direita em torno de um partido histórico (PP) e dos dois novos partidos (Ciudadanos e Vox) sendo este último de direita radical. Mediante diversas fontes de evidência empírica que incluem dados de opinião pública, de especialistas e programas eleitorais, aborda-se a orientação, perfil ideológico e posicionamentos em matéria territorial dos três partidos de direita que tem presença em toda a Espanha. O trabalho revela a existência de espaços de proximidade entre os três partidos que se contrapóem às orientaçóes de partidos de outros blocos. Ao mesmo tempo, a análise evidencia as nuances nas posiçóes entre o PP, Vox e Ciudadanos que nos permitem falar da existência de competiçáo no interior do bloco de direita pela conquista de espaços e de eleitores.

\section{Palavras-chave}

Direita; Partidos Políticos; Ideologia; Clivagem Territorial; Competição Eleitoral.

\begin{abstract}
Among the different changes that have taken place in the Spanish party system, this article tackles the end of one single party's hegemony on the right of the ideological spectrum. Further attention is needed to analyze the emergence of a three-party logic within the right wing, consisting of a historic party (PP) and two new ones (Ciudadanos and Vox), being the latter a radical right-wing party. A wide variety of empirical evidence including public opinion data, experts' data and analysis of electoral programs is used to study the three rightwing parties' orientation, their ideological profiles, as well as their positions on the territorial cleavage. The work highlights the existence of closeness between the three parties in contrast to other political parties' positions. At the same time, the analysis discovers nuances in political positions among PP, Vox and Ciudadanos that allow competition within right-wing parties regarding issues and voters.
\end{abstract}

\section{Keywords}

Right Wing; Political Parties; Ideology; Territorial Cleavage; Electoral Competition. 


\section{Introdução}

O sistema de partidos da Espanha experimentou transformaçóes importantes em dimensôes como a fragmentação, a polarização e em seu grau de nacionalização. Este artigo se foca em uma das mudanças que ocorreu recentemente: a gestação de um novo bloco de direita que inclui um partido histórico e dois novos partidos, sendo um deles de direita radical. Isso marca o fim da hegemonia de mais de três décadas de um único partido de direita relevante na Espanha.

Desde a consolidação do sistema de partidos surgido com a Transição, a centrodireita espanhola se agrupou paulatinamente em torno de um único partido: Aliança Popular (AP), refundado posteriormente como Partido Popular (PP). Por sua vez, a centro-esquerda, a nível nacional, foi ocupada por dois partidos em competiçáo embora cada vez mais desigual - o PSOE e o PCE, posteriormente integrado na Izquierda Unida (IU). Após várias décadas, o surgimento no campo da esquerda de Podemos, agora Unidas Podemos (UP), e o salto a nível nacional do outrora centrista Ciudadanos (C's) em 2014 e 2015, respectivamente, parecia centrar essa competiçáo ao centro e esquerda, enquanto o campo da direita permanecia intacto.

No entanto, a aparição de um partido à direita do PP, denominado Vox, juntamente com a recente virada de C's nesta direção, teve como consequência a criação de uma competiçâo multipartidária no bloco de direita até o momento inédita. Ao mesmo tempo, a emergência de Vox pôs fim à "excepcionalidade espanhola" como um dos poucos países imunes aos movimentos radicais de direita (TURNBULLDUARTE, 2019). Apesar de Vox não ser o único partido de direita radical populista e extrema-direita que já existiu na Espanha e que obteve representação política, nunca antes havia conseguido tanta força eleitoral e parlamentar, tornando-se no terceiro maior partido depois das eleiçôes de 2019. A direita radical espanhola teve a oportunidade de emergir eleitoralmente após o abandono da simbologia fascista, a articulação de um novo discurso, a interconexáo internacional, bem como a normalização e a naturalização de elementos-chave do discurso e do ideário da direita radical em contextos sociais não necessariamente vinculados com a extrema direita (ÁLVAREZ, 2019).

O presente trabalho analisa a evolução e as características desse novo bloco de direita na Espanha, formado na atualidade por PP, Ciudadanos e Vox. São partidos diferentes entre si, com uma institucionalização própria e inequívoca de seus processos de organização interna. Náo obstante, os três partidos lutam por eleitores com traços ideológicos semelhantes. Essa competição no campo da direita entre os três partidos leva a falar de bloco ideológico, no sentido cunhado por Sani e Sartori (1983) ao 
estudarem a polarização dos sistemas partidários. A noção de bloco alude a uma proximidade ideológica que não implica necessariamente processos de convergência ou entendimento entre as organizaçóes partidárias. A existência de um grupo de partidos que formam um bloco ideológico não sugere que este atuará de forma coordenada em eleiçôes nem em pactos de governo.

O primeiro objetivo do trabalho é proporcionar uma reflexão sobre a evolução da direita na Espanha que permita compreender a conformação deste polo na atualidade. Com isso se fornece indicações da evolução histórica dos partidos de direita que se formaram na Segunda República e que convergiram em um mesmo espaço a partir da Transição. O segundo objetivo é analisar as diferenças e semelhanças entre os três partidos que ocupam a direita tanto no eixo ideológico como no eixo territorial. Trata-se de caracterizar os espaços que ocupam os três partidos a partir de diferentes evidências empíricas, com o fim de avaliar as distâncias entre as distintas opçóes partidárias que integram o espaço da direita em dois planos centrais da política espanhola na atualidade.

Para alcançar ambos os objetivos da pesquisa, primeiramente será exposta a evolução da direita e da extrema direita na Espanha, para depois nos centrarmos em dois aspectos essenciais para definir a natureza desses partidos e suas interaçôes. Por um lado, serão abordadas as orientaçôes e o perfil ideológico deste bloco. Por outro, serão analisadas suas posições em matéria territorial, já que este novo tipo de competição nos três partidos de direita nacional tem sido acompanhado pelo questionamento do modelo territorial das autonomias. Frente ao desafio independentista cataláo, Vox tornou-se a ponta de lança dos partidários de iniciar um recorte nas competências transferidas para as Comunidades Autônomas, enquanto os demais partidos de âmbito nacional continuam defendendo, de uma forma ou de outra, o modelo das autonomias. Assim, o consenso geral sobre o modelo de Estado parece ter se rompido.

Essas questôes serão analisadas mediante uma variada evidência empírica. Serão utilizados dados do CIS (Centro de Investigaciones Sociológicas), que reúne as posiçôes dos cidadãos sobre diversos temas, os programas dos partidos políticos facilitados pelo Grupo Manifesto Project, bem como dados recentes da pesquisa de especialistas Global Party Survey (GPS), que se concentra em valores, temas e retórica populistas (NORRIS, 2019).

As hipóteses que guiam o trabalho são que, no bloco de direita, existe um grau considerável de proximidade em sua orientação geral, no espaço ideológico ocupado por seus partidos, bem como em suas posiçôes em questóes territoriais. Esta 
proximidade cria incentivos para a competição da direita com outros blocos e/ou com outros partidos. Porém, ao mesmo tempo e apesar dessa proximidade, existem nuances diferenciáveis entre os três partidos de direita que produzem uma competição por ocupar espaços e por eleitores no interior do bloco.

$\mathrm{Na}$ seção seguinte, é feita uma revisão dos antecedentes históricos dos partidos de direita e extrema direita na Espanha. A terceira seção caracteriza esse bloco de direita com base em sua orientação e perfis ideológicos. A quarta seção mapeia as posições dos três partidos em matéria territorial. Finalmente, há uma seção de conclusões.

\section{Antecedentes da direita na Espanha}

A aparição de um bloco de direita nacional, no sentido de Sani e Sartori (1983), formado na atualidade por três partidos, pode ser considerada uma novidade dentro do sistema de partidos que se consolidou após a Transição. No entanto, não é menos verdade que a gestação desse bloco deve ser entendida no quadro de uma síntese complexa de diversas tradiçóes unidas por visôes, ideias e interesses comuns, mas igualmente opostas entre si em muitos aspectos (GONZÁLEZ e MONTERO, 2001). Por isso, um primeiro esclarecimento refere-se à consideração de que existem diferentes tradiçốes dentro da direita. Nesse sentido, é necessário diferenciar precisamente entre a direita e a extrema direita. As organizaçôes de direita incluem tanto os partidos conservadores como os democratas-cristãos; enquanto na extrema direita inclui-se grupos tradicionais contrarrevolucionários, conservadores autoritários e fascistas. Os valores, ideias e apoio à democracia liberal pluralista variam entre esses dois grandes grupos.

Esse fato nos leva a um segundo esclarecimento conceitual - a distinção entre extrema direita e direita radical. Apesar da tendência de utilizá-las de forma intercambiável, a discussão teórica forneceu vários argumentos para a necessidade de diferenciá-las. Muitos autores contribuíram para estender o conceito de extrema direita para denominar todos os partidos situados à direita dos partidos conservadores ou democratas-cristãos (VON BEYME, 1988; IGNAZI, 2003; MUDDE, 1996, entre outros). Mas foi recentemente que começaram a se refinar mais as várias posiçóes dentro da própria extrema direita. Mudde (2007) destacaria que esses partidos formavam, junto com a direita radical, um subgrupo da família mais ampla da ultradireita (FERREIRA, 2019). Há uma diferença fundamental entre eles: os partidos de direita radical aceitam as instituiçôes democráticas e suas regras do jogo, embora se oponham a alguns fatores fundamentais da democracia liberal, enquanto a extrema direita é antidemocrática (MUDDE, 2007). É verdade que ambos compartilham 
característica como liderança, nacionalismo, populismo e autoritarismo, embora também existam certas nuances diferenciáveis. Por exemplo, a extrema direita se opóe ao comunismo, defende uma visão mítica da nação com referências normalmente imperialistas, reivindica a ideia racial da Europa branca e a expulsão de imigrantes por razôes biológicas e hierárquicas, ou defende um Estado interventor e regulador. Em contraste, a direita radical não só teme o comunismo, mas também a modernidade, rejeita o atual Estado-nação como decadente e corrupto como consequência da globalização, do multiculturalismo e de sua elite política. Portanto, eles não buscam um império, mas se trata de uma luta contra um coletivo, não aceitam toda aquela população que não é etnicamente assimilável, principalmente a muçulmana, e não são claramente protecionistas porque criticam fortemente o Estado de Bem-Estar, embora exijam medidas protecionistas para a produção nacional, defendam a intervenção do Estado no controle de fronteiras e na garantia de benefícios sociais. Ambos os tipos de ultradireita compartilham a ideia de um líder carismático, salvador e protetor dos cidadãos frente aos partidos (RODRÍGUEZ, 2006).

Como indica Zulianello (2019), esse surgimento de novos e cada vez mais relevantes partidos de direita radical torna necessário entender também o seu nível de integração no sistema partidário. Atualmente, percebe-se que um número crescente desses atores está integrado ao sistema partidário, interagindo com outras forças políticas e formando ou podendo formar coalizóes de governo ou eleitorais, embora sem necessariamente renunciar à sua ideologia antiestablishment.

Esses esclarecimentos conceituais são fundamentais, portanto, para entender a relação, o posicionamento e as interaçôes entre os três partidos que compóem o novo bloco de direita na Espanha. Apesar de sua emergência recente, na Espanha o fenômeno da extrema direita e da direita radical não é algo novo, já que desde a Restauração no século XIX até hoje sempre esteve presente em sua história, embora com muitas dificuldades para se consolidar e permanecer no tempo. Tanto é verdade que se apontava a excepcionalidade da Espanha em comparação com o aprofundamento do movimento de direita radical em outros países da Europa.

A seguir, destacam-se alguns aspectos da evolução histórica do sistema partidário espanhol que podem ajudar a entender algumas dinâmicas do atual bloco de direita. 


\section{A origem dos partidos de direita e de extrema direita}

O sistema partidário do século XIX na Espanha girou em torno da oposição entre duas opçôes: o confronto absolutismo-liberalismo, a oposição entre moderados e progressistas durante o reinado de Isabel II, e a oposição entre conservadores e liberais após a Restauração Monárquica de 1875 (MARCET, 2012). Isso duraria, com suas respectivas variaçóes, até quase o advento da Segunda República.

Junto com essa direita, também emergiu a extrema direita política na Espanha, representada por um pensamento "tradicionalista" fortemente influenciado por correntes antirrevolucionárias e ultrarreligiosas, com pensadores como Donoso Cortés, Jaime Blames, Vázquez de Mella ou Víctor Pradera, caracterizados pelo seu catolicismo, antiliberalismo e, posteriormente, a importância da tradição, da monarquia e da unidade da Espanha através do regionalismo e do foralismo (DUÑAITURRIA, 2017). Essas ideias centrais do pensamento da extrema direita terão uma grande influência na extrema direita espanhola até hoje.

A direita e a extrema direita caracterizaram-se por sua grande pluralidade interna, incluindo a carlistas, social-católicos, mauristas e nacionalistas periféricos, e por constituir-se em movimentos cívicos contrários à secularização (MARCET, 2012). Posteriormente, durante o período Alfonsino, que foi marcado pelas ditaduras de Primo de Rivera, Berenguer e Bautista Aznar (1923-1931), à extrema direita espanhola juntou-se um setor militar ultraconservador, antiliberal e antidemocrático, que teve sua forma na Unión Patriótica. Esse partido de caráter único, fundado pelo Capitão General Primo de Rivera, tinha como objetivo substituir os partidos tradicionais e dar suporte a um novo regime, seguindo os mesmos passos do Partido Popular Italiano. Esse partido tentou desenvolver o caráter tradicional social cristão ao integrar nele a direita tradicional católica (antiliberal e antidemocrática), os mauristas e os conservadores.

Durante a Segunda República, o papel da direita foi claramente o de guerra política aberta enquanto lhes foi possível, e de inspiração e apoio ao levante militar de julho de 1936 - que desencadearia a guerra civil de 1936-1939 - quando consideraram acabada a via política para reconquistar e manter o poder (MARCET, 2012). Após a mudança de regime, os partidos dinásticos desapareceram completamente (GONZÁLEZ e MONTERO, 2001). É aqui que surge a Confederação Espanhola de Direitas Autônomas (CEDA), o primeiro movimento de massas da direita espanhola e que se tornaria o principal partido durante a República, com um ideário católico-social que inclui o confessionalismo, o corporativismo social e político, o anti-laicismo, a 
função subsidiária do Estado, o reformismo social etc. (GONZÁLEZ e MONTERO, 2001).

A extrema direita também evoluiu, adquirindo um caráter etnotradicionalista, contrarrevolucionário e contrário ao sistema político vigente, com partidos como a Acción Española, que se caracterizava por uma "exaltação da tradição", o reconhecimento histórico da religião católica e o estabelecimento da monarquia (DUNAAITURRIA, 2017). Junto com ela surgiram partidos mais radicais, de tipo fascista, que anos mais tarde contribuiriam para o golpe militar de julho de 1936, em que se destacam o Partido Nacionalista Español, as Juntas de Ofensiva Nacional Sindicalista (JONS) e a Falange Espanhola (FE), que se unificariam em 1937, com Franco, na Falange Tradicionalista Española y de las JONS, que formará, junto com o Sindicato Vertical, o "Movimento Nacional". Este movimento desenvolveu uma ideologia em que se misturaram elementos da direita mais tradicional (antiliberalismo, antissocialismo, nacionalismo exaltado, catolicismo conservador, defesa da propriedade e interesses...) com contribuiçóes do ideário falangista mais próximo do pensamento fascista europeu (DUNAAITURRIA, 2017).

À medida que o regime de Franco avançou, com seu afastamento gradual das abordagens falangistas e a consequente aproximação a certos setores católicos e à Opus Dei, começaram a se desenvolver entidades de ultradireita que seriam muito relevantes e que mais uma vez mostraram a divisão da direita antes da chegada da Transição (RODRÍGUEZ, 2006). Assim, foram fundados a Fuerza Nueva de Blas Pińar, que afirmava representar o "espírito de 18 de julho", e o Círculo Español de Amigos de Europa (CEDADE), um movimento nazista pan-europeu (RODRÍGUEZ, 2006). O surgimento das duas entidades foi o prelúdio do que seria uma ampla mobilização daqueles que viam com alarme como o regime se distanciava de seus princípios fundadores, configurando uma extrema direita beligerante em seu seio: o chamado "bunker" (CASALS, 2009). Portanto, não é de se estranhar que, durante o período de transição, duas orientações opostas foram formalizadas na direita - de um lado, a extrema direita que busca dar continuidade ao regime franquista e se opóe à transiçáo democrática, e de outro, aqueles que tentam fazer, com maior ou menor nostalgia do passado, a passagem para um novo regime democrático (GALLEGO, 2008).

\section{Direita: da divisão à hegemonia}

Durante os primeiros anos da Transiçáo, a direita seguiu dividida. A extrema direita e a direita radical, nostálgica do franquismo, não conseguiram durante a 
114 | Fabio Lupato, Leticia M. Rodríguez e Gema Medero

Transição nem nas décadas seguintes se cristalizar em uma ou mais forças políticas com representação institucional relevante e estável (RODRÍGUEZ, 2012). Na verdade, desde 1976, foram criados vários partidos de diferentes tipos e abrangências territoriais, mas com uma característica comum, sua irrelevância eleitoral (NIETO-ALISEDA CAUSO, 2014) ante a incapacidade de tornar a impossibilidade hegemônica uma tendência do reformismo franquista (GALLEGO, 2008). Nisso reside a "excepcionalidade espanhola" que se manterá, como se verá mais adiante, com alguma exceção regional até o crescimento eleitoral de Vox nas eleiçóes autonômicas da Andaluzia de dezembro de $2018^{1}$. Esse momento, reforçado pelos resultados das eleiçôes gerais de abril e novembro de 2019, comprova o fim dessa excepcionalidade.

Quadro 1 - Partidos de extrema direita e direita radical na Espanha (1976)

\begin{tabular}{|l|c|c|c|}
\hline Partido & Criaçáo & Classificaçáo & $\begin{array}{l}\text { Âmbito } \\
\text { territorial }\end{array}$ \\
\hline Falange Espańola de las JONS & 1976 & Extrema-direita & Nacional \\
\hline Movimiento Católico Espańol (MCE) & 1982 & Extrema-direita & Nacional \\
\hline Democracia Nacional (DN) & 1995 & Direita-radical & Nacional \\
\hline Estado Nacional Europeo (ENE) & 1995 & Extrema-direita & Nacional \\
\hline Falange (FE) & 1999 & Extrema-direita & Nacional \\
\hline Movimiento Social Republicano (MSR) & 1999 & Extrema-direita & Nacional \\
\hline Falange Auténtica (FA) & 2002 & Extrema-direita & Nacional \\
\hline Plataforma per Catalunya (PxC) & 2002 & Direita-radical & Nacional \\
\hline Espańa 2000 (E-2000) & 2002 & Direita-radical & Nacional \\
\hline Alternativa Espańola (AES) & 2003 & Direita-radical & Nacional \\
\hline Identidade Galega (IDEGA) & 2004 & Direita-radical & Autonômico \\
\hline Alianza Nacional (AN) & 2005 & Extrema-direita & Nacional \\
\hline Alianza Municipal Espańola (AME) & 2007 & Direita-radical & Nacional \\
\hline Partido Familia y Vida (PFyV) & 2012 & Extrema-direita & Nacional \\
\hline Partido por la Libertad (PxL) & 2013 & Extrema-direita & Nacional \\
\hline Vox & 2013 & Direita-radical & Nacional \\
\hline Iniciativa por Albacete (IxAb) & 2014 & Direita-radical & Autonômico \\
\hline $\begin{array}{l}\text { Plataforma Democrática per Catalunya } \\
\text { (PDxC) }\end{array}$ & 2014 & Direita-radical & Autonômico \\
\hline Som Identitaris (SOMI) & 2016 & Extrema-direita & Autonômico \\
\hline
\end{tabular}

\footnotetext{
${ }^{1}$ Outras forças políticas também conseguiram isso, como a Unión Nacional, que era uma aliança eleitoral formada pela Fuerza Nueva, FE de las JONS, Círculos Doctrinales José Antonio, Confederación Nacional de Excombatientes e Agrupación de Juventudes Tradicionalistas, para participar das eleições gerais de 1979 (NIETO-ALISEDA CAUSO, 2014). E no nível municipal, a Plataforma por Catalunya (PxC) conseguiu o mesmo.
} 
Fonte: Elaboração própria com base em Morencos (2019).

Enquanto isso, também emerge uma direita moderada que apoia a Transição e que se materializa em dois grupos. Por um lado, a UCD de Adolfo Suárez, que liderou a Transição a partir do governo, mas que declina em 1982. Esse partido, composto pelos setores mais favoráveis à abertura do franquismo e pequenos grupos da oposição democrática mais moderada (MARCET, 2012), era muito dependente da figura do próprio Suárez. Além deste partido, havia uma opção adicional de direita, a Alianza Popular, com uma visão nostálgica do franquismo e que foi criada por sete ex-ministros franquistas, dos quais se destacava Manuel Fraga (RODRÍGUEZ-AGUILERA, 2017). Muitos dos membros da UCD passariam posteriormente para a Alianza Popular (AP) ${ }^{2}$. Assim, será a AP que passa a liderar a centro-direita e a direita espanholas durante o novo período democrático. Apesar de, no início, os resultados eleitorais serem relativamente ruins, três fatores permitirão que se torne o partido hegemônico da centro-direita espanhola. Por um lado, como já assinalamos, pela limitada capacidade organizativa e eleitoral da extrema direita e da direita radical. Em certa medida, isso se deve ao fato de que os movimentos enquadrados nessa extrema direita náo souberam se adaptar às mudanças, necessidades e mesmo medos da sociedade espanhola e ainda mantinham as mesmas mensagens que haviam utilizado durante a Transição (DUNAAITURRIA, 2017). Por outro, como segundo fator, os poderes de fato do franquismo decidiram jogar dentro das regras do sistema democrático e se organizaram para competir eleitoralmente por meio da AP (MARCET, 2012; GALLEGO, 2008). Em terceiro lugar, o desaparecimento da UCD permitiu à Alianza Popular usufruir de um amplo espaço que, sob a liderança de José María Aznar, promoveria um projeto unificador que "conseguiu integrar toda a centro-direita espanhola", tradicionalmente muito fragmentada, como foi visto (RODRÍGUEZ-AGUILERA DE PRAT, 2017, p. 320). Sua estratégia era formar uma “maioria natural”, reunindo em um único partido a toda a direita para ser uma força política com apoio eleitoral significativo e criar um "[...] partido de base ampla onde caibam e convivam comodamente as ideias liberais, conservadoras e democratas-cristãs" (MARCET, 2012. p. 15-16). O PP se tornou, afinal, uma alternativa crível de governo, que alcançaria em 1996 e que significou também a neutralização eleitoral da extrema direita, “[...] com a captura do voto útil por uma direita cuja normalização democrática não impediu sua ascendencia sobre

\footnotetext{
${ }^{2}$ Outros integrantes da antiga UCD formaram novas forças políticas de orientação regionalista ou nacionalista, como, por exemplo, a Unión del Pueblo Navarro, as Agrupaciones Independientes de Canarias (atual Coalición Canaria) e outros criaram o Centro Democrático Social (CDS).
} 
setores radicais [...] em um processo de seleção racional do voto útil” (CASALS, 2009, p. 151).

Em conclusão, a evolução da direita, da extrema direita e da direita radical na Espanha mostra grande fragmentação e divisão, mas também uma série de valores e ideias que, de uma forma ou de outra, foram conservados ao longo do tempo (RODRÍGUEZ, 2006). Por exemplo, herdaram aspectos como o catolicismo, uma certa identidade comum ou uma concepçáo tradicionalista de unidade nacional (RODRÍGUEZ, 2006).

\section{A formação e os perfis ideológicos do bloco de direita}

A crise de 2008, a corrupção e o problema cataláo foram o pano de fundo para a criação de novos partidos que desafiaram a condiçáo monopartidarista de direita na Espanha, gerando uma transformação para um bloco multipartidário. Essa perda de hegemonia do PP teve dois partidos como protagonistas.

O primeiro a aparecer foi Ciudadanos, um partido que surgiu na Catalunha, criado por uma série de intelectuais agrupados na plataforma cívica Ciutadans de Catalunya com um objetivo claro, a oposição e crítica ao nacionalismo catalão e que nos mostra a crescente relevância da dimensão territorial na competição política. Apesar da sua juventude, já viveu várias etapas com bons e maus resultados eleitorais, além de algumas decisóes polêmicas, como o seu envolvimento com o grupo de direita e eurocéptico Libertas nas eleições europeias de 2009 (RODRÍGUEZ-AGUILERA DEL PRAT, 2017). Foi nas eleiçôes de 2015 que Ciudadanos deixou de ser um partido minoritário do âmbito cataláo para entrar com força no nível nacional (ORRIOLS e CORDERO, 2016; RODRÍGUEZ-TERUEL e BARRIO, 2016). Quanto ao seu credo, a princípio definiu-se como um partido constitucionalista, pós-nacionalista, liberal e progressista e, posteriormente, como um partido liberal progressista e aconfessional. $\mathrm{Na}$ sua relação com o $\mathrm{PP}$, a pressão eleitoral de C’s supunha o surgimento de um partido de nível nacional que se posicionava como liberal na dimensão econômica, mas também mais progressista em relação aos seus valores sociais, em oposiçáo ao maior conservadorismo do PP.

O segundo partido que colocou em xeque a hegemonia do PP foi Vox. Este partido radical de direita foi criado no final de 2013 e atualmente possui uma clara institucionalizaçáo organizacional. Vox nasceu com o objetivo de "[...] recolher o voto da direita desencantada com as políticas do PP” e se focou na política antiterrorista, na unidade da Espanha - novamente a importância da clivagem territorial - e na regeneração democrática (GRACIA, 2014). Apesar disso, seus resultados eleitorais, 
muito em linha com a extrema direita e a direita radical espanholas, foram anedóticos até sua irrupção nas eleiçóes andaluzas de dezembro de 2018 e, sobretudo, nas eleiçóes gerais de abril de 2019, quando alcançou um amplo grupo parlamentar no Congresso dos Deputados. Os dirigentes que fundaram Vox deixaram as fileiras do PP insatisfeitos com a política de Mariano Rajoy diante da crise econômica, incluindo seu atual líder, Santiago Abascal, seu primeiro candidato eleitoral nas eleiçóes europeias de 2014, Alejo Vidal-Cuadras, que foi Europarlamentar do PP e seu antigo presidente na Catalunha (FERREIRA, 2019).

Como resultado do desafio colocado primeiro por C's e depois por Vox, existe atualmente um bloco de direita nacional formado por esses três partidos, que repartem um percentual de apoio semelhante ao que conseguia sozinho o PP em 2011 (ver Gráfico 1).

Gráfico 1 - Percentual de votos (e número de cadeiras) no bloco de direita nacional

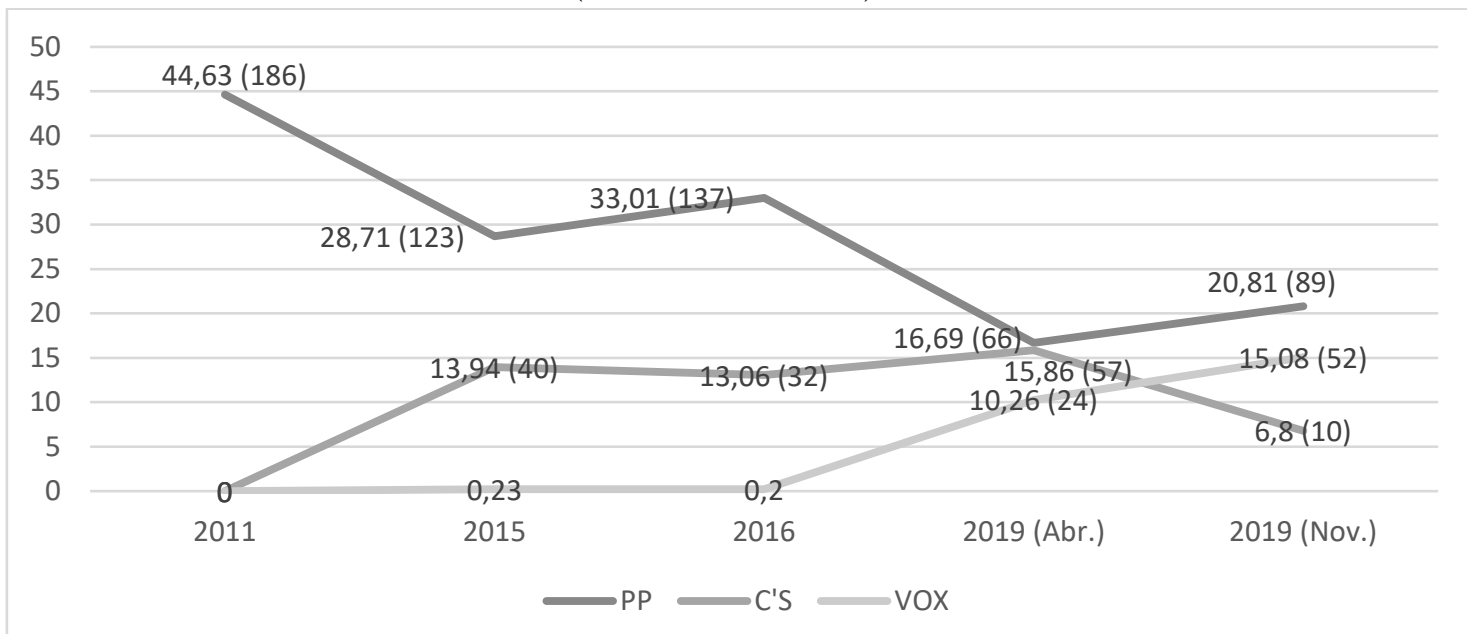

Fonte: Dados do Ministério do Interior (ESPAÑA, c2013). Elaboração própria.

\section{Orientação e perfil ideológico do novo bloco da direita}

A transformação da direita espanhola de um bloco monopartidário em um multipartidário requer uma compreensão profunda. Nesta seção, é traçada uma aproximação da orientação e do perfil ideológico desses partidos para destacar as diferenças interpartidárias em suas identidades e nas posiçôes que defendem, bem como no tipo de eleitorado que os apoia. 
Do ponto de vista da sua orientaçáo geral, as respostas dos especialistas recolhidas no Global Party Survey (GPS) mostram que o carácter conservador/liberal, por um lado, bem como a marca populista/pluralista por outro, são dois vetores de diferenciação entre Vox, PP e Ciudadanos (ver Tabela 2) ${ }^{3}$. Se trata de três tipos de direita diferenciáveis entre si, entre outras questóes, no caráter populista que os especialistas do GPS dão a Vox e à sua retórica contra algumas das instituições básicas do sistema frente à condição pluralista de PP e Ciudadanos. Da mesma forma, entre estes dois últimos, as diferenças se concentram em seus valores, devido ao caráter conservador do PP e liberal de Ciudadanos. Na verdade, essas diferenças se refletem na própria filiaçáo desses partidos nas famílias europeias presentes no Parlamento Europeu, onde o bloco de direita espanhol se dividiu em três grandes correntes. Assim, enquanto o PP faz parte do Partido Popular Europeu, C’s está em Renew Europe - a família liberal, enquanto Vox está com os Conservadores e Reformistas Europeus.

Quadro 2 - Valores e populismo no bloco da direita

\begin{tabular}{|l|c|c|c|}
\hline & VOX & PP & C's \\
\hline $\begin{array}{l}\text { Tipo de valores do } \\
\text { partido }\end{array}$ & $\begin{array}{c}\text { Direita- } \\
\text { Conservador }\end{array}$ & Direita-Conservador & Direita-Liberal \\
\hline Tipo Populismo & $\begin{array}{c}\text { Fortemente } \\
\text { Populista }\end{array}$ & Moderadamente pluralista & Moderadamente pluralista \\
\hline $\begin{array}{l}\text { Tipo valores } \\
\text { populistas }\end{array}$ & $\begin{array}{c}\text { Populista } \\
\text { conservador }\end{array}$ & Pluralista conservador & Pluralista liberal \\
\hline
\end{tabular}

Fonte: Global Party Survey (NORRIS, 2019).

Então, quais aspectos são semelhantes e diferentes em sua orientação ideológica? A análise dos espaços ideológicos que esses partidos ocupam na dimensão esquerda-direita confirma a proximidade entre os partidos ao mesmo tempo em que sublinha a existência de nuances. Os dados do CIS coletados a partir das localizações atribuídas pelos eleitores de todos os partidos a cada uma das organizaçôes confirmam a expectativa de que Ciudadanos seja o partido mais moderado dos três partidos de

\footnotetext{
${ }^{3}$ A tipologia dos valores partidários é construída através de duas variáveis binárias que incluem se eles têm valores econômicos de esquerda (a favor do Estado) ou de direita (pró mercado) juntamente com valores progressivos (liberdades pessoais, democráticas, participação, casamento entre pessoas do mesmo sexo) ou conservadores; o tipo de populismo do partido remete à retórica pluralista ou populista, entendendo esta última como uma linguagem que vai contra a legitimidade das instituições políticas estabelecidas, enfatizando a vontade geral do povo. Finalmente, o tipo de valores populistas é construído por meio de duas variáveis, a retórica populista juntamente com os valores sociais (NORRIS, 2019).
} 
direita de nível nacional (Gráfico 2). Além disso, com a única medição existente de Vox (ano 2019), se confirma a sua também previsível condição de organizaçáo partidária mais à direita das três que são analisadas ${ }^{4}$.

Da mesma forma, essa evidência empírica desmonta duas crenças relacionadas a Ciudadanos. Por um lado, segundo a percepção dos eleitores de todos os partidos, Ciudadanos nunca esteve no centro ideológico, como o partido inicialmente se autoatribuía. Por outro, o lugar que se atribui a Ciudadanos não apresenta grandes oscilaçôes ao longo do tempo. Isso estaria em contradição com as acusaçôes que foram feitas pelos diferentes partidos políticos ao grupo laranja e seu líder anterior, Albert Rivera, de uma crescente mudança para posiçóes mais orientadas para a direita.

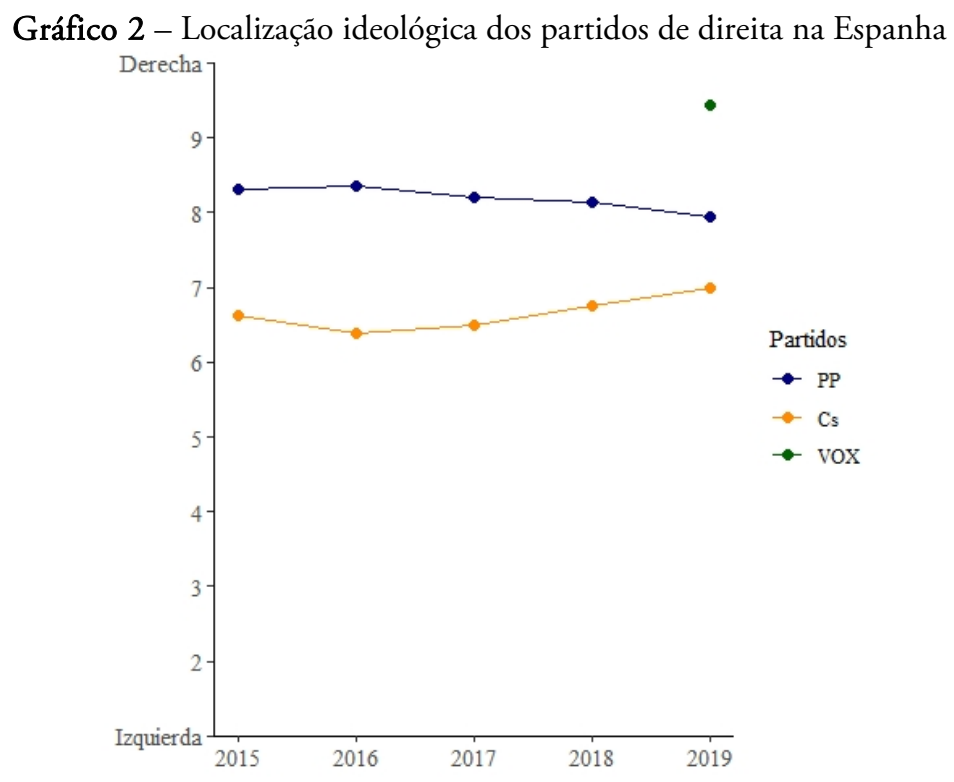

Fonte: Ruiz, Otero e Pellicer (2019).

Por outro lado, a análise do plano ideológico também confirma a existência de esferas compartilhadas e esferas concorrentes entre os três partidos. O Gráfico 3 mostra os níveis de sobreposição entre as posições ideológicas dos três partidos políticos, dando

\footnotetext{
${ }^{4}$ Os dados CIS são congruentes com os da pesquisa de especialistas em GPS, que atribuem uma posição a Vox $(9)$, PP $(7,8)$ e C's $(7,7)$ no eixo esquerda-direita com base em seu posicionamento em relação a uma maior ou menor intervenção do Estado na economia, sendo 1 intervenção máxima e 10 intervenção mínima.
} 
pistas sobre a possibilidade de uma distribuição racional do espaço da direita. Vox e PP seriam mais sobrepostos do que Ciudadanos e PP. Também se verifica que a sobreposição entre Ciudadanos e Vox é baixa. Isso coloca o PP numa posição de maior risco: o desafio de manter sua identidade, não perder eleitores e ganhar eleitores de outros partidos. Com esse indicador, tem-se uma ideia do espaço comum que os partidos do mesmo sistema possuem e, além disso, da medida em que competem pelo mesmo eleitorado 5 . A interpretação da figura é simples, as cores mais escuras indicam uma sobreposição muito alta, próxima de 1 , uma intensidade mais baixa corresponderia a níveis médios do indicador $(0,5)$, e os mais claros, próximos ao branco, ficariam abaixo de 0,25 , revelando uma sobreposição reduzida.

De forma complementar, a Gráfico 4 traça os nichos ideológicos dos partidos para abordar visualmente o fenômeno da interação entre os três partidos no plano ideológico. O nicho refere-se à área retangular onde são apresentadas as posiçôes ideológicas dos partidos ${ }^{6}$. Um nicho grande é típico daqueles partidos com maior indefinição em seu perfil ideológico, que podem atrair um eleitorado maior e ao mesmo tempo mais heterogêneo ideologicamente. Ao contrário, um nicho de tamanho reduzido será característico de partidos muito especializados ideologicamente. Assim, em 2019 a área ocupada por cada um dos três partidos é semelhante; um pouco menor no caso de Vox. O PP é o que mais divide espaço com outros partidos, enquanto Vox e Ciudadanos têm espaços próprios, além daqueles que compartilham com o PP.

\footnotetext{
${ }^{5}$ Para calcular a sobreposição, foram utilizadas as localizações ideológicas dos eleitores dos partidos políticos em cada eleição. $\mathrm{O}$ indicador foi calculado em pares de partidos e varia entre $0 \mathrm{e}$ 1. Se a sobreposição estiver próxima de 1, ocorre uma alta sobreposição ideológica entre os dois partidos. Ao contrário, um resultado próximo a 0 indica muito pouca sobreposição (LLAMAZARES e SANDEL, 2003; RUIZ e OTERO, 2013).

${ }^{6}$ Os nichos são calculados a partir da representação das médias e dos desvios-padrão em duas dimensões: a primeira refere-se à localização do partido na escala esquerda e direita em uma escala de 1 a 10 de acordo com os eleitores de todos os partidos (eixo de abscissa), e a segunda se refere à localização dos eleitores do partido na mesma escala (eixo das ordenadas). Dessa forma, o tamanho das áreas indica o grau de especialização ideológica que cada partido político possui (RUIZ e OTERO, 2013).
} 
Gráfico 3 - Sobreposição ideológica de partidos de direita na Espanha

\section{9}

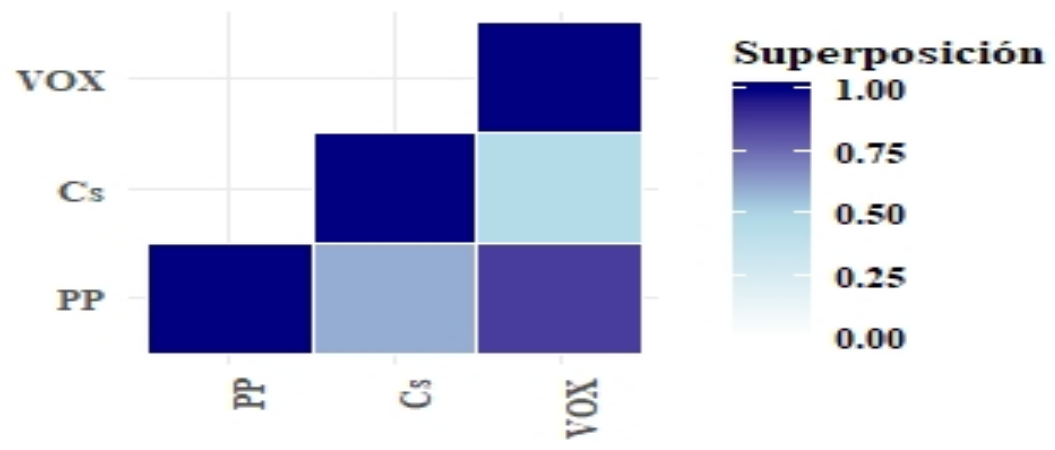

Fonte: Ruiz, Otero e Pellicer (2019).

Gráfico 4 - Especialização - Nichos dos partidos de direita na Espanha (2019)

$$
2019
$$

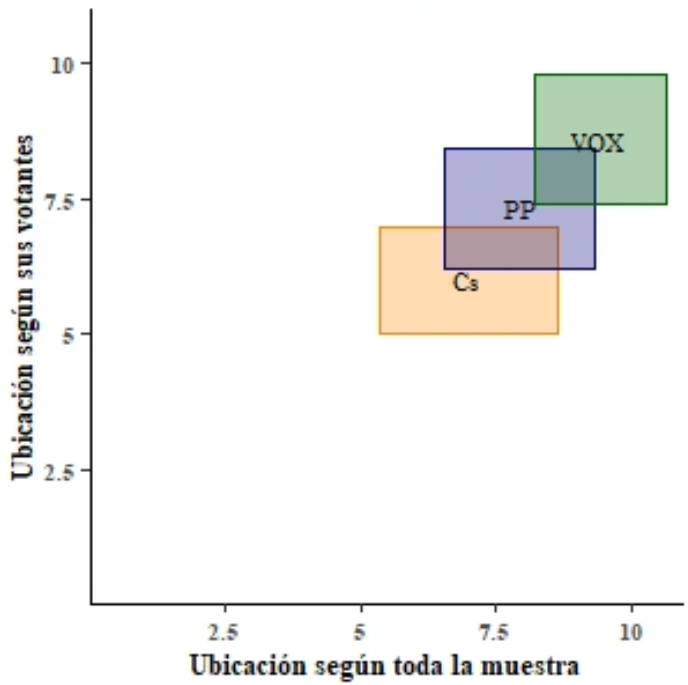

Partidos

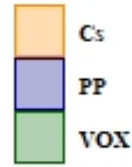

Fonte: Ruiz, Otero e Pellicer (2019).

Reconhecendo que os partidos de direita no nível nacional estão próximos uns dos outros e que partilham alguns eleitores, podemos nos perguntar qual desses partidos 
tem eleitores mais diversificados. Para responder, a Gráfico 5 mostra os níveis de coerência ou, dito de outra forma, o grau de discordância entre os eleitores dos três partidos em suas autolocalizaçôes ideológicas. Como foi calculado aqui, um coeficiente de concordância próximo a 1 indicaria um alto nível de coerência (os eleitores coincidem com sua autocolocação ideológica) ${ }^{7}$, enquanto valores próximos a 0 indicariam níveis menores de coerência (eleitores de um mesmo partido apresentam diferenças em sua autocolocação ideológica). De acordo com os dados, Ciudadanos teria um eleitorado mais coerente entre os partidos de âmbito nacional atualmente ${ }^{8}$. Seus eleitores estariam mais de acordo entre si em suas autolocalizaçóes ideológicas. Já o eleitorado de Vox, na única medição que temos (2019), é o partido com eleitorado mais heterogêneo no plano ideológico. A falta de coerência nessa dimensão sugere a capacidade do partido de atrair perfis de eleitores diferentes entre si.

Portanto, o bloco formado pelos partidos de direita gera situaçóes de grande proximidade entre si, mas com diferentes graus de sobreposição. O PP está na posição de maior risco ao competir com Ciudadanos e Vox pelos eleitores de ambos os partidos. Além disso, os dados sugerem que o Vox é, neste momento, o partido que atrai os eleitores mais diversos entre si.

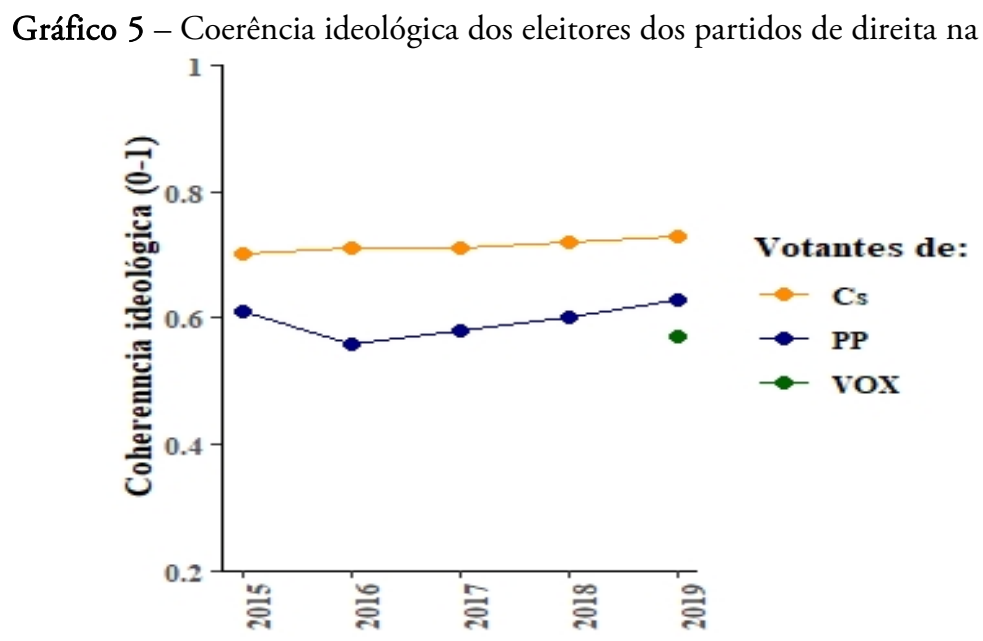

Fonte: Ruiz, Otero e Pellicer (2019).

\footnotetext{
${ }^{7}$ Ver Ruiz e Otero (2013) sobre o conceito e as formas de calcular a coerência partidária.

${ }^{8}$ Embora os dados sobre a cristalização dos partidos não sejam apresentados aqui, pode-se notar que as pesquisas do CIS mostram dos três partidos.
} 


\section{As posições dos partidos de direita na clivagem territorial}

A relevância da clivagem territorial constitui um aspecto distintivo do sistema de partidos espanhol e, especificamente, na evolução do bloco de direita nacional. Uma das características do sistema partidário espanhol é, precisamente, a existência de numerosos partidos de âmbito não nacional (PANE) ${ }^{9}$ (BARRIO et al., 2010) que também configuram uma heterogeneidade do sistema partidário espanhol em âmbito regional (OCAÑA e OÑATE, 2005) e que têm grande relevância sistêmica. Diante desse papel dos PANE, tanto C's quanto Vox surgiram, entre outras coisas, em face da crítica profunda ao nacionalismo periférico e ao funcionamento do Estado das Autonomias. Isso se tornou ainda mais relevante com o conflito na Catalunha. Não é à toa que existe uma discussão sobre o papel do processo catalão no surgimento dos novos partidos no bloco da direita nacional ${ }^{10}$.

\section{O ressurgimento do centralismo}

Durante décadas se falou na Espanha de um consenso descentralizador refletido na afirmaçáo de Linz que garantia que o apoio residual da opiniáo pública ao centralismo, já no início da década de 1980, se devia ao fato de que nenhum partido defendia essa forma de Estado (LINZ, 1985; TORCAL e MOTA, 2014; MARTÍNEZ-HERRERA e MILEY, 2010). Esse não é um processo único da Espanha; de maneira similar, Mazzoleni (2009), ao analisar a regionalização nos sistemas de partido britânico, francês e italiano, conclui que se produz a aceitação da descentralização em todos os partidos do sistema.

Tabela 1 - Preferências sobre o modelo de organização territorial do Estado, por lembrança de voto e Comunidades Autônomas (CCAA) (2019)

\begin{tabular}{l|c|c|c|c|c|c|c}
\hline & C's & PP & VOX & Espanha & Catalunha & $\begin{array}{c}\text { País } \\
\text { Basco }\end{array}$ & Galícia \\
\hline $\begin{array}{l}\text { Um Estado com um } \\
\text { único Governo } \\
\begin{array}{l}\text { Central. } \\
\hline\end{array}\end{array}$ & 19,1 & 30,1 & 47,8 & 15,9 & 7,9 & 2,9 & 13,0 \\
\hline
\end{tabular}

\footnotetext{
${ }^{9}$ N. T. No original partidos de âmbito no estatal

${ }^{10}$ A este respeito, são ilustrativas as declarações do president da Catalunha, Quim Torra (2019), no Washington Post, nas quais argumentou que não era o independentismo, mas as "divisões internas e lutas pelo poder" dentro do PP que deram ascensão ao seu ressurgimento porque, na realidade, a extrema direita espanholista sempre esteve aí. Por outro lado, no mesmo meio e como resposta, o professor Sergi Pardos-Prado (2019) destacou que, apesar do fato de que a imigração poderia ser um fator relevante no surgimento de Vox, a oposição ao secessionismo foi ideologicamente essencial para seu aparecimento e consolidação.
} 
Fabio Lupato, Leticia M. Rodríguez e Gema Medero

\begin{tabular}{l|c|c|c|c|c|c|c}
\hline $\begin{array}{l}\text { Um Estado com } \\
\begin{array}{l}\text { CCAA com menor } \\
\text { autonomia }\end{array}\end{array}$ & 27,6 & 21,7 & 16,8 & 13,0 & 3,2 & 2,1 & 10,1 \\
\hline $\begin{array}{l}\text { Um Estado com } \\
\begin{array}{l}\text { CCAA como na } \\
\text { atualidade }\end{array}\end{array}$ & 42,2 & 37,9 & 24,8 & 43,3 & 26,0 & 25,4 & 53,8 \\
\hline $\begin{array}{l}\text { Um Estado com } \\
\text { CCAA com maior } \\
\text { autonomia. }\end{array}$ & 6,0 & 3,5 & 4,4 & 12,0 & 24,0 & 28,8 & 12,3 \\
\hline $\begin{array}{l}\text { Um Estado que } \\
\text { reconhecesse às CCAA } \\
\text { a possibilidade de } \\
\text { serem Estados } \\
\text { independentes }\end{array}$ & 0,9 & 0,0 & 0,0 & 7,9 & 32,8 & 33,8 & 3,8 \\
\hline \begin{tabular}{l} 
NS/NC \\
\hline
\end{tabular}
\end{tabular}

Fonte: CIS 3252 para as primeiras quatro colunas. CIS 3253 para os dados da Catalunha, País Basco e Galiza. Elaboração própria.

Décadas depois, como pode ser visto na Tabela 1, esse consenso sobre a descentralização regional foi rompido. Os votantes dos três partidos analisados apresentam preferências quanto à recentralização e ao centralismo substancialmente superiores à média de toda a Espanha, e são ainda mais divergentes quando comparados com a Catalunha e o País Basco. 46,7\%, 51,8\% e 64,6\% dos eleitores de C's, PP e Vox, respectivamente, estão a favor de reduzir de alguma forma a autonomia das CCAA. Da mesma forma, enquanto uma minoria majoritária dos eleitores de C's está a favor do status quo atual, quase a metade dos eleitores de Vox opta por um modelo de Estado centralista, e os votantes do PP estão divididos entre o status quo e um maior centralismo. Em todo caso, os votantes dos três partidos estão bastante (ou muito) distantes das preferências médias dos eleitores espanhóis e apresentam uma tendência muito diferente dos votantes catalães e bascos. A relevância do conflito territorial para os eleitores também é evidenciada, adicionalmente, na pesquisa pós-eleitoral de CIS (Estudo 3269, de dezembro de 2019). Quando questionados se o que aconteceu recentemente na Catalunha influenciou no voto nas eleiçôes, mais de um terço dos 
eleitores do PP e C's (35,0\% e 55,9\% respectivamente) e mais da metade dos de Vox $(55,9 \%)$, afirmam que sim, em comparação com $24,2 \%$ da média espanhola ${ }^{11}$.

Junto com a posição dos eleitores, é interessante observar o momento em que $\mathrm{o}$ apoio difuso à descentralização ${ }^{12}$ começou a se desgastar. Para fazer isso, primeiro analisaremos os dados fornecidos pelo Projeto Manifesto ${ }^{13}$. O Gráfico 1 nos mostra a evolução da posição sobre centralização e descentralização desde 1989. Vários aspectos merecem destaque, embora seja necessário pontuar que os últimos dados publicados não contemplam as eleiçóes de abril e novembro de 2019, nem as últimas eleições analisadas (2016) codificam o programa eleitoral do Vox, devido ao percentual de votos muito residual da época. Assim, em primeiro lugar, desde a fundação do Partido Popular em 1989, até 2015, verifica-se que neste partido as mençóes relativas ao eixo territorial se enquadram na lógica de apoio ao sistema autônomo. De fato, em todas as eleiçôes, o programa eleitoral do PP contém muito mais mençóes positivas do que negativas em relação à descentralização, chegando a não ter qualquer mençáo ao centralismo (eleiçôes de 2004). Além disso, as mençóes positivas da descentralização são sempre maiores do que as ideias recentralizadoras ${ }^{14}$.

Essa posição eminentemente positiva em relação à descentralização está em sintonia com a dos restantes partidos de âmbito nacional (PSOE, IU), que, de fato, apresentam um nível ainda mais elevado de referências à descentralização, que, na maioria dos casos, não vêm acompanhadas de menção (ou esta é muito residual) à

\footnotetext{
${ }^{11}$ Apenas os eleitores dos partidos de âmbito catalão ERC e Junts, com 60,5\% e 63,2\% respectivamente, apresentam um valor superior (e En Comú Podem, com 36,2\%).

${ }^{12}$ Um debate complementar, que extrapola os objetivos deste trabalho, é analisar se são os partidos que seguem as preferências de seus eleitores ou se a causalidade é inversa. Sobre essas questões você pode ler Fernández-Albertos e Lago (2015), Pardos-Prado (2019), Vergé (2013) e Barrio e Rodríguez Teruel (2017).

${ }^{13}$ Esse projeto analisa os programas eleitorais para as eleições gerais em mais de 50 países, incluindo a Espanha, proporcionando as posições dos partidos nas mais diversas políticas através da análise do conteúdo das "quase frases" incluídas nos programas eleitorais e analisar a relevância que os partidos atribuem a certas questões e políticas (BUDGE, 1994; BUDGE et al., 2001; KLINGEMAN et al., 2006). Nessa análise de conteúdo, são apresentadas duas variáveis relacionadas à posição dos partidos em relação ao eixo territorial. De um lado, referências à descentralização, ou seja, apoio ao federalismo, descentralização política e/ou econômica, maior autonomia das instituições subnacionais (incluindo os municípios); de outro, as referências à centralização, que supõe "[...] oposição generalizada à tomada de decisões políticas nos níveis políticos mais baixos”, com apoio a um governo unitário e maior centralização política e administrativa. Em suma, permite conhecer a relevância do eixo territorial por partidos e eleições desde 1977.

${ }^{14}$ No entanto, alguns autores, como Vergé (2013), sustentam que é a partir dos anos 2000 que o PP inicia a sua evolução para um maior centralismo.
} 
centralização. Porém, os dados mostram uma mudança qualitativa a partir das eleições de 2015. A relevância total do tema, a soma das mençôes a descentralização e centralização cai pela metade em relação às eleiçóes anteriores. Além disso, as menções a favor da centralização são superiores, pela primeira vez, às mençôes à descentralização. Essa importante mudança pode estar ligada, junto com as demandas de regeneração do sistema político que levou à criação de outros partidos na esfera da esquerda, ao fim da aceitação do modelo de descentralizaçáo vigente, que se observa claramente, por outro lado, com o conflito independentista catalão.

Isso é ainda mais pronunciado no caso de Ciudadanos, que surgiu na Catalunha e se expandiu pela Espanha com duas ideias principais, a regeneração democrática e a luta contra o independentismo (RODRÍGUEZ-TERUEL e BARRIO, 2016). Essa linha é consistente tanto com a relevância total do tema (que é quatro vezes maior do que a do PP em 2016), bem como com a sua composição. Nesse sentido, a grande maioria das mençóes está na linha da centralização e não tanto da descentralização. A emergência do C's parece mostrar a importância do eixo territorial no surgimento de novos partidos no bloco de direita.

Gráfico 1 - Evolução da centralização-descentralização nos PP e C's

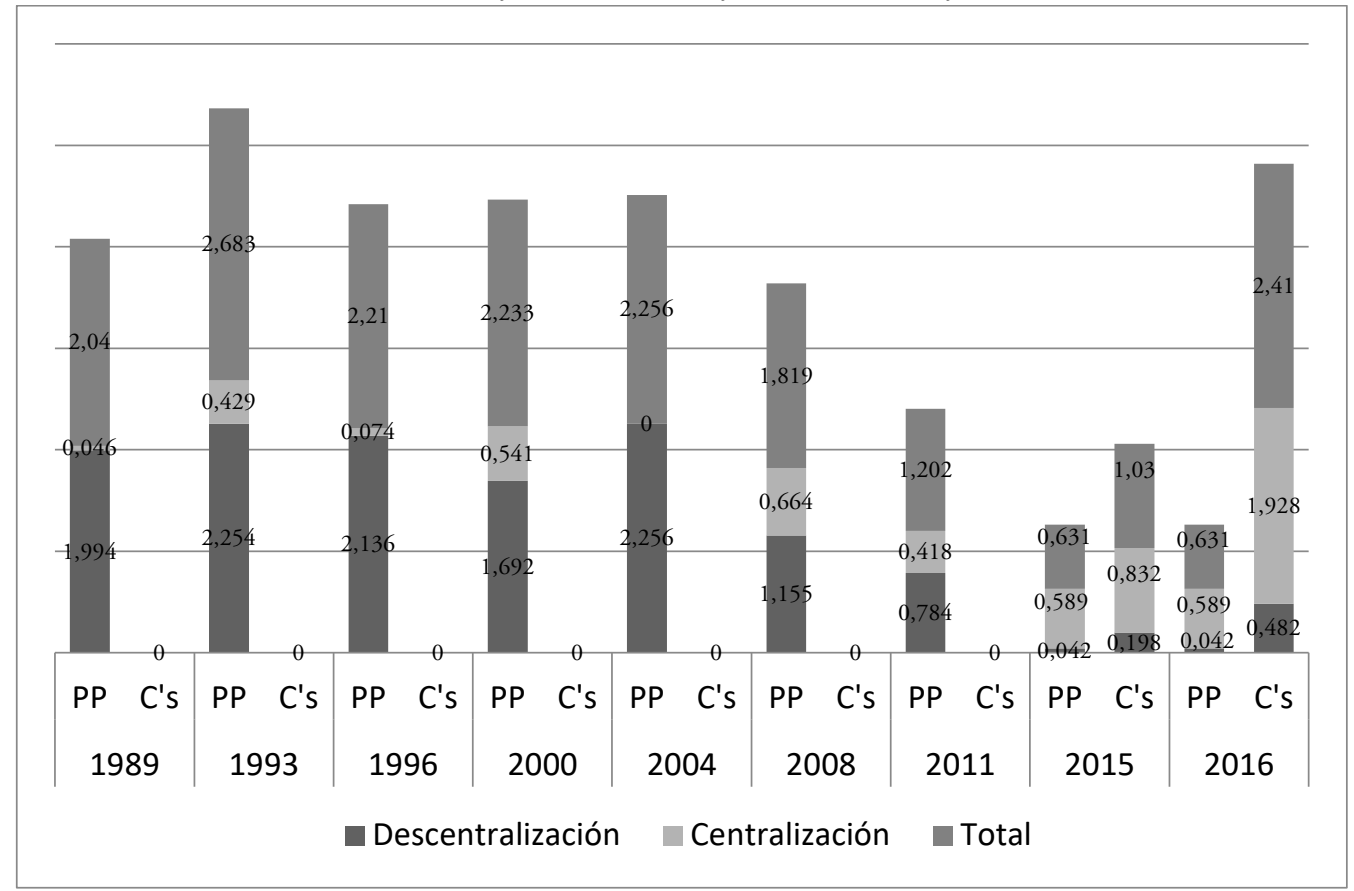

Fonte: Elaboração própria a partir de dados do Manifesto Project. 


\section{As propostas dos partidos sobre o eixo territorial}

Finalmente, para analisar como os partidos do bloco de direita se posicionam e competem, analisaremos os programas eleitorais das eleiçóes gerais de 2019. Para isso, nos centraremos nas quatro dimensóes-chave para o estudo da descentralização (HOOGHE, MARKS e SCHAKEL, 2010; VERGE, 2013). A primeira dimensão é o autogoverno, que se refere ao grau de autonomia das unidades subnacionais. A segunda dimensão é o governo compartilhado (ou co-governo), que enfoca o papel das regióes na tomada de decisóes em nível nacional. A terceira é a preferência ou o reconhecimento de uma certa (a)simetria entre as regióes - em termos de suas competências ou financiamento, por exemplo. Por fim, o reconhecimento ou não da ideia de plurinacionalidade e especificidades culturais próprias de certas regióes em relaçáo a outras. Como os três partidos do bloco da direita se posicionam nessas dimensōes?

No que diz respeito aos dois primeiros - autogoverno e co-governo - os três partidos são a favor de uma maior recentralização, garantindo a presença do Estado em todo o território e, portanto, limitando também a possibilidade de governo compartilhado. Apesar disso, existe uma diferença substancial entre PP e C's, por um lado, e Vox, por outro. Os dois primeiros partidos reconhecem o papel das CCAA e muitas das suas competências, embora critiquem certos desvios de competências e, sobretudo, proponham o reforço do papel do Estado central. O PP, em seu programa de abril de 2019, expressa muito claramente essa ideia de recentralização, mas não de Estado centralista: "[se] em 1978 a modernização do país passou pela descentralização, hoje, em 2019, o principal desafio que temos é o de fortalecer a capacidade de espinha dorsal do Estado para garantir a liberdade e a igualdade de todos os espanhóis" (PP, 2019a, p. 6). Como no caso do C's, ambos os partidos se propóem a clarificar competências, retomar o controle de certas políticas - entre elas, o das forças de segurança do Estado e uma maior supervisão dos meios audiovisuais públicos, a educação, a saúde, entre outras. No entanto, também reconhecem em outras políticas a necessidade de coordenação com as diversas autonomias e a necessária e estreita colaboração. Em vez disso, Vox se afasta dessa ideia de recentralização. Em seu programa, propóe " $[\mathrm{t}]$ ransformar o Estado autonômico em um Estado de Direito unitário que promova a igualdade e a solidariedade em vez dos privilégios e da divisão. Um único governo e um só parlamento para toda a Espanha" (VOX, 2019, p. 3). Ao mesmo tempo, propõe recuperar as competências da Educação, Saúde, Segurança e Justiça, limitando a 
capacidade legislativa autonômica. De fundo subjaz um modelo territorial com um único governo central e o fim do Estado das Autonomias.

Tabela 4 - A posição dos três partidos nas quatro dimensôes da descentralização

\begin{tabular}{l|c|c|c|c}
\hline & Autogoverno & Cogoverno & Assimetria & Plurinacionalidade \\
\hline PP & Recentralização & Sim/Não & Não & Não \\
\hline Cs & Recentralizaçáo & Sim/Não & Não & Não \\
\hline Vox & Centralismo & Não & Não & Não \\
\hline
\end{tabular}

Fonte: Elaboração própria com base nos programas partidários (CIUDADANOS, 2019; PP, 2019a e 2019b, VOX, 2019).

Uma terceira dimensão faz referência à possível assimetria entre Comunidades Autônomas. Sempre existiu uma tensão no desenvolvimento do sistema autônomo quanto à possibilidade de tratamento desigual - ao nível de competência, atribuiçóes, financiamento ou reconhecimento de especificidades culturais - entre Comunidades Autônomas. Nesse sentido, os três partidos opóem-se à existência de competências diferentes ou exclusivas de certas Comunidades Autônomas. Isto é evidente, por exemplo, no tema do financiamento. C's propóe um "sistema de financiamento autonômico sem privilégios", com a reforma do sistema de o financiamento autonômico para "um modelo mais justo, equitativo e transparente" (CIUDADANOS, 2019, ponto 21) e a eliminação do "privilégio supóe" o cálculo da quota basca. Por sua vez, Vox propóe a “[...] supressão do Acordo Econômico Basco e do Acordo Navarro e a incorporação de ambas as regióes e seus Conselhos Forais ao Regime Comum" (VOX, 2019, p. 3). Isto também se reflete claramente na política educacional, na qual os três partidos fazem referência à necessidade de reafirmar o castelhano como língua veicular na educação, mas, acima de tudo, introduzindo elementos uniformes no sistema educacional descentralizado, como "seletividade única em toda a Espanha" (CIUDADANOS, 2019, ponto 37), a "realização de provas acadêmicas de nível nacional" (PP, 2019b, ponto 61) ou "implantar exames de controle em nível nacional” ao finalizar cada etapa educativa (VOX, 2019, ponto 64). De fato, Ciudadanos (2019, ponto 35) propóe "[...] um sistema educacional e não 17 para acabar com a desigualdade entre os espanhóis [...] para evitar que aqueles que querem romper a Espanha continuem fazendo política nas salas de aula com nossos filhos". Da mesma forma, no acesso ao emprego público, os três partidos observam que o espanhol será a única língua indispensável, não podendo ser considerado o conhecimento de outro idioma co-oficial um "requisito excludente" (PP, 2019b, X), 
"que as línguas co-oficiais nunca sejam uma barreira" (CIUDADANOS, 2019, ponto 225), ou diretamente "suprimir o requisito de conhecimento da língua co-oficial no acesso à função pública” para evitar a discriminação (VOX, 2019, ponto 4). Ainda, em aspectos da política de saúde, é solicitado um calendário único de vacinação (PP, 2019b, ponto 79; CIUDADANOS, 2019, ponto 59).

Finalmente, junto com esta ideia de defesa da simetria e da igualdade entre os cidadãos espanhóis, está a noção de identidade e a concepçáo da Espanha como um Estado nacional ou plurinacional. Como observado acima, a noção de igualdade para todos os espanhóis é central nos os três partidos e está ligada a uma certa percepção da identidade espanhola. De qualquer forma, os três partidos apresentam propostas que, de um modo ou de outro, tornam visível a ideia de uma única nação, seja com uma Lei dos Símbolos Nacionais que garanta a utilização da bandeira nacional nos edifícios oficiais e o retrato do Chefe de Estado nos plenários municipais (PP, 2019b); ou com a "máxima proteção jurídica aos símbolos da nação" e um "plano integral para o conhecimento, difusão e proteção da identidade nacional”, a contribuição da Espanha para a civilização universal e "os feitos dos heróis nacionais" (VOX, 2019, pontos 3 e 8).

Em suma, se observam novos posicionamentos que colocam em questão o equilíbrio do atual sistema autonômico. A mudança pela qual passou o sistema de partidos espanhol tem reflexo também nas preferências em relação ao modelo regional. Outros partidos propóem uma crescente lógica federal e, consequentemente, maior cogoverno, assimetria e até plurinacionalidade. Essa lógica pode ser observada no PSOE, que fixou sua posição na Declaração de Granada (de julho de 2013) para ir "avançando para o federalismo, com todas as suas consequências" (PSOE, 2013, p. 5), ou a defesa de uma proposta de Espanha plurinacional defendida por Podemos e suas confluências (ver, por exemplo, o livro Repensando la España plurinacional, de 2017, com a participação de vários dos principais líderes do partido). Por outro lado, alguns PANEs, especialmente os de âmbito catalão, defenderam a independência, como ERC e Junts. Diante dessas posiçóes, os partidos nacionais de direita propóem uma reforma do Estado autonômico no sentido de uma maior (re)centralização. Isso ficou marcado na manifestação pela unidade da Espanha, que aconteceu no dia 10 de fevereiro de 2019 e que contou com a participação dos líderes dos três partidos, exemplificando assim um nexo entre eles com o tema territorial como um dos pontos centrais. Portanto, existem todas as bases para a politização, com uma questão relevante, capaz de mobilizar a população, e com posiçôes diferenciadas entre os diferentes atores políticos. Frente ao resto das propostas, os partidos do bloco de direita apresentam semelhanças, 
embora, como já apontamos, algumas divergências que fazem da clivagem territorial e a forma do Estado autonômico um tema estratégico tanto nas dinâmicas internas entre os três partidos como frente às propostas de outros partidos políticos.

\section{Conclusões}

A formação de uma direita tripartida que substitui a hegemonia monopartidária do PP constitui uma das mudanças profundas vividas pelo sistema partidário espanhol e que requer uma análise detalhada. Especificamente, o trabalho tratou de fornecer alguns dos traços da evoluçáo da direita na Espanha e de analisar o grau de proximidade e as nuances de valores, perfil ideológico e posiçóes em matéria territorial entre os três partidos políticos em nível nacional que atualmente ocupam o espectro da direita na Espanha.

Em relação ao primeiro objetivo, o trabalho explica as mudanças cíclicas na direita na Espanha. Se mostrou que a fragmentação no âmbito da direita é suscetível de experimentar grandes oscilaçóes. Desde a Segunda República e em períodos anteriores, articularam-se organizaçóes partidárias que capturavam diferentes sensibilidades de direita. Posteriormente, a partir da transição para a democracia, a fragmentaçáo no meio da direita diminuiu à medida que o PP adquiria a condiçáo de partido hegemônico. E décadas depois se entra em um novo ciclo no qual a unidade da direita se desgastou. Fruto disto se institucionalizaram diferentes opçóes partidárias que redesenham um panorama de fragmentação que se traduz em uma oferta multipartidária de direita.

Quanto ao segundo objetivo, demonstrou-se que, ao contrário das divisóes e confrontos que historicamente caracterizaram a direita na Espanha, atualmente existem nítidos elementos de proximidade entre os três partidos políticos analisados, embora também possam ser apontadas âmbitos de diferenciação em suas posições políticas que estariam por trás dessa situação de multipartidarismo na direita. A combinação de distância e proximidades leva a estratégias de colaboração entre os três partidos políticos, bem como à competição para ocupar espaços e conquistar eleitores.

Em primeiro lugar, no que diz respeito à orientação geral dos valores dos três partidos, os dados de especialistas mostram a condição populista de Vox frente ao pluralismo conservador do PP e ao pluralismo liberal de Ciudadanos. Em segundo lugar, a análise dos espaços ideológicos com os dados da opinião pública mostra as diferenças no perfil ideológico dos partidos, embora haja uma clara proximidade entre eles. Além disso, mostra-se que o PP estaria na posição de maior risco, compartilhando eleitores com Ciudadanos e Vox ao mesmo tempo. Em terceiro lugar, essa competição 
entre os partidos também é evidente em suas posiçôes sobre a clivagem territorial. Embora os três partidos sejam críticos de certos aspectos do Estado das Autonomias, Vox opta por um Estado unitário frente a uma posição mais matizada do PP e C's. Sendo assim, os partidos podem ser levados a competir entre si e a politizar temas relativos à identidade nacional e à relação entre as autonomias, o que inclui, como vimos, certos aspectos culturais com uma longa tradição histórica na direita, extrema direita e direita radical espanhola. No entanto, da mesma forma que os pode levar a competir dentro do bloco, também é verdade que a clivagem territorial pode funcionar como elemento que facilite o entendimento entre eles diante do restante do sistema, facilitando, por exemplo, as coalizóes para enfrentar e competir contra outros partidos - especialmente onde os nacionalismos periféricos são especialmente fortes - ou, quando for o caso, como políticas compartilhadas para formar governos em outras regiôes. Por exemplo, uma coalizão entre PP e C's, com o apoio parlamentar de Vox, governa nas CCAA da Andaluzia, Madri e Murcia. Além disso, PP e C's se apresentaram juntos nas eleiçóes autonômicas no País Basco, onde ambos os partidos obtiveram recentemente resultados eleitorais ruins, e em Navarra, juntamente com a Unión del Pueblo Navarro, onde se tornaram a primeira força política da comunidade.

Em suma, a presente abordagem empírica ao bloco de direita que surgiu na Espanha revela três novidades. A primeira é que existe uma competição no espaço da direita - em termos ideológicos, econômicos, de valores e territoriais - inédita desde a consolidação do sistema partidário após a Transição. Os três partidos têm incentivos para politizar certos temas e competir dentro do bloco para lutar pela propriedade de certas políticas e ganhar votos. Mas, além disso, têm influência na competição interblocos, politizando certos temas - ideologia, valores e clivagem territorial - com posiçóes similares frente ao resto dos partidos, facilitando sua cooperação. A segunda novidade é o aparecimento de Vox, que póe fim a uma suposta excepcionalidade espanhola, ao contar agora com um partido de direita radical com grande força eleitoral. Pela primeira vez desde a Transição, a plêiade de partidos e eleitores de extrema direita e direita radical parece ter encontrado um partido com grande força eleitoral e vocação para a permanência no tempo, quebrando a hegemonia do PP em relaçâo a esse tipo de eleitor. É preciso notar que, embora possamos falar de um bloco de direita, sua composiçáo interna tem variado e pode mudar ainda mais, dependendo da capacidade de C's de recuperar-se após a mudança de liderança devido a seus resultados eleitorais recentes. A terceira novidade é que o bloco da direita, junto com os outros partidos do sistema, pôs em questáo o consenso descentralizador, que tem 
uma grande relevância no sistema e um forte potencial divisivo tanto no nível do bloco quanto em todo o sistema de partidos.

Fabio García Lupato é Professor da Universidad Complutense de Madrid. E-mail: fglupato@ucm.es.

- Leticia M. Ruiz Rodriguez é Professora da Universidad Complutense de Madrid. E-mail: leticiamaria.ruiz@cps.ucm.es.

- Gema Sánchez Medero é Professora da Universidad Complutense de Madrid. E-mail: gsmedero@cps.ucm.es.

\section{Referências}

ÁLVAREZ, Antonio N. Elementos para análisis de la nueva extrema derecha española. In: DÍEZ GARCÍA, Rúben; BENTACOR NUEZ, Gomer (Coords.). Movimientos sociales, acción colectiva y cambio social en perspectiva: continuidades y cambios en el estudio de los movimientos sociales. Bizakai: Betiko Fundazioa, 2019. p. 59-69.

BARRIO, Astrid et al. Partidos de ámbito no estatal y gobernabilidad multinivel: el caso de Espańa (1977-2008). Working Papers, n. 291, p. 1-25, 2010.

BUDGE, Ian. A new spatial theory of party competition: Uncertainty, ideology and policy equilibria viewed comparatively and temporally. British Journal of Political, v. 24, n. 4, p. 443-467, 1994.

BUDGE, Ian et al. Mapping policy preferences. Oxford: Oxford University Press, 2001.

CASALS, Xavier. La renovación de la ultraderecha española: Una historia generacional (1966-2008). Historia y Política, v. 22, p. 233-258, 2009.

CENTRO DE INVESTIGACIONES SOCIOLOGICAS (CIS). Estudio 3269: barómetro de diciembre 2019. Postelectoral elecciones generales 2019. 2019. Disponível em: <http://www.cis.es/ cis/opencm/ES/1_encuestas/estudios/ver.jsp?estudio=14479>. Acesso em: 23 maio 2021.

CIUDADANOS. Programa electoral. 2019. Disponível em: <https://www.ciudadanoscs.org/programa-electoral>. Acesso em: 11 fev. 2020.

DUNAAITURRIA, Gonzalo. Análisis de las causas de la irrelevancia de la derecha radical populista en España (1978-2015). Una excepción en el contexto político europeo. 2017. 453 f. Tese (Doutorado em Direito) - Facultad de Derecho y Economía, Universidad Camilo José Cela, Madrid, 2017.

ESPAÑA. Ministerio del Interior. Consulta de Resultados Electorales. [Portal del Ministerio del Interior], c2013. Disponível em: <http://www.infoelectoral.mir.es/infoelectoral/min/ >. Acesso em: 31 jul. 2021.

FERNÁNDEZ-ALBERTOS, José; LAGO, Ignacio. Gobiernos autonómicos e identidades regionales en Espańa, 1980-2012. Política y Gobierno, v. 22, n. 2, p. 283-315, 2015. 
FERREIRA, Carles. Vox como representante de la derecha radical en España: Un estudio sobre su ideología. Revista Española de Ciencia Política, v. 51, p. 73-98, 2019.

GALLEGO, Ferran. Nostalgia y modernización. La extrema-derecha española entre la crisis final del franquismo y la consolidación de la democracia (1973-1986). Ayer, v. 71, p. 175-209, 2008.

GONZÁlEZ, Pedro C.; MONTERO, Feliciano. Los conservadores españoles en el siglo XX. In: MORALES MOYA, Antonio (Coord.). Las claves de la España del siglo XX. Valencia: Sociedad Estatal España Nuevo Milenio, 2001. p. 39-62.

GRACIA, Ana I. Abascal y Ortega Lara le montan a Rajoy la primera escisión del PP en dos décadas. El Confidencial, 15 jan. 2014. Disponível em: <https://www.elconfidencial.com/espana/2014-0115/abascal-y-ortega-lara-le-montan-a-rajoy-la-primera-escision-del-pp-en-dos-decadas_76238/>.

Acesso em: 23 maio 2021.

HOOGHE, Liesbet; MARKS, Gary; SCHAKEL, Arjan H. Rise of regional authority. Londres: Routledge, 2010.

IGNAZI, Piero. Extreme right parties in Western Europe. Oxford: Oxford University Press, 2003.

KLINGEMAN, Hans-Dieter et al. Mapping policy preferences II: Estimates for parties, electors, and governments in Eastern Europe, European Union and OECD 1990-2003. Oxford, Oxford Unviersity Press, 2006.

LINZ, Juan J. De la crisis de un Estado Unitario al Estado de las Autonomías. In: FERNÁNDEZ RODRÍGUEZ, Fernando (Ed.). La España de las Autonomías. Madrid: Instituto de Estudios de la Administración Local, 1985. p. 527-672.

LLAMAZARES, Iván; SANDEL, Rick. Partidos políticos y dimensiones ideológicas en Argentina, Uruguay, México y Chile. Revista Polis. Investigación y Análisis sociopolítico, v. 0, n. 99, p. 43-69, 2003.

MNIFESTO PROJECT. [Database]. Disponível em: <https://manifesto-project.wzb.eu/>. Acesso em: 31 jul. 2021.

MARCET, Joan. La derecha en España: Una aproximación histórica. Working Papers, n. 306, 2012.

MARTÍNEZ-HERRERA, Enric; MILEY, Thomas J. The constitution and the politics of national identity in Spain. Nations and Nationalism, v. 16, n. 1, p. 6-30, 2010.

MAZZOLENI, Martino. The saliency of regionalization in party systems. Party Politics, v. 15, n. 2, p. 199-218, 2009.

MORENCOS, Victor. Las estrategias de institucionalización de la nueva derecha radical española, 2002-2017. Política y Gobernanza, Revista de Investigación y Análisis Político, v. 3, p. 75-102, 2019.

MUDDE, Cas. Populist radical right parties in Europe. Cambridge: Cambridge University Press, 2007.

MUDDE, Cas. The war of words. Defining the extreme right party family. West European Politics, v. 19, p. 225-248, 1996.

NORRIS, Pippa. The Global Party Survey. 2019. Disponível em: <https://www.globalpartysurvey. org/>. Acesso em: 2 fev. 2020. v. 1.0.

NIETO-ALISEDA CAUSO, Rafael A. La extrema derecha en la Transición: Juntas Españolas y El Alcázar. Aportes, v. 86, n. 39, p. 177-206, 2014.

OCAÑA, Francisco A.; OÑATE, Pablo. Elecciones excepcionales, elecciones de continuidad y sistemas de partidos. In: MONTERO, José M.; LAGO, Ignacio; TORCAL, Mariano (Eds.). Las elecciones generales de 2004. Madrid: Centro de Investigaciones Sociológicas, 2005. p. 225-246. 
ORRIOLS, Lluis; CORDERO, Guillermo. The breakdown of the Spanish two-party system: The upsurge of Podemos and Ciudadanos in the 2015 general election. South European Society and Politics, v. 21, n. 4, p. 469-492, 2016.

PARDOS-PRADO, Sergi. Spain finally has a radical-right party in parliament. Why did it take so long? The Wahsington Post, May 10, 2019. Disponível em: <https://www.washingtonpost.com/ politics/2019/05/10/spain-finally-has-radical-right-party-parliament-why-did-it-take-solong/?utm_term=.6bbfec19dee4>. Acesso em: 17 maio 2019.

PARTIDO POPULAR (PP). Programa electoral. 2019a. Disponível em: <http://www.pp.es/sites/ default/files/documentos/programa-electoral-elecciones-generales-2019.pdf>. Acesso em: 24 jan. 2020.

PARTIDO POPULAR (PP). Programa electoral noviembre 2019. 2019b. Disponível em: $<$ http://www.pp.es/sites/default/files/documentos/pp_programa_electoral_2019.pdf>. Acesso em: 24 jan. 2020.

PARTIDO SOCIALISTA OBRERO ESPAÑOL (PSOE). Ganarse el futuro. Un nuevo pacto territorial: la España de todos. 6 jul. 2013.

RODRÍGUEZ-AGUILERA, Cesareo. Manual de partidos políticos. Barcelona: Huygens, 2017.

RODRÍGUEZ, José L. Historia de un fracaso y ¿̇e una refundación? De la vieja a la nueva extremaderecha en España (1975-2012). Studia Historica, v. 30, p. 231-268, 2012.

RODRÍGUEZ, José L. De la vieja a la nueva extrema-derecha (Pasando por la fascinación por el fascismo). Historia Actual Online, v. 9, p. 87-99, 2006.

RODRÍGUEZ-TERUEL, Juan; BARRIO, Astrid. Going national: Ciudadanos from Catalonia to Spain. South European Society and Politics, v. 21, n. 4, p. 587-607, 2016.

RUIZ, Leticia M.; OTERO, Patricia. Indicadores de partidos y sistemas de partidos. Cuaderno Metodológico, n. 51, 2013.

RUIZ, Leticia M.; OTERO, Patricia; PELLICER, Manuel. Perfiles ideológicos de los votantes de los partidos políticos españoles. Ayudas a equipo investigador para la explotación de datos del CIS, dic. 2019.

SANI, Giacomo; SARTORI, Giovanni. Polarization, fragmentation and competition in Western Democracies. In: HANS, Daalder; MAIR, Peter (Eds.). Western European Party Systems. Beverly Hills: Sage, 1983. p. 301-340

TORCAL, Mariano; MOTA, Fabiola. The role of political parties in shaping citizens' political preferences for the territorial organization of the state: the Spanish case. European Political Science Review, v. 6, n. 3, p. 477-502, 2014.

TORRA, Quim. The catalan independence movement is not behind the rise of Spain's far right. The Washington Post, May 6, 2019. Disponível em: <https:/www.washingtonpost.com/ opinions/2019/05/07/catalan-independence-movement-is-not-behind-rise-spains-farright/?utm_term=.87ad75074597>. Acesso em: 17 maio 2019.

TURNBULL-DUARTE, Stuart. Explaining the end of Spanish exceptionalism and electoral support for Vox. Research \& Politics, p. 1-8, abr./jun., 2019.

VAN DER EIJK, Cees. Measuring agreement in ordered rating scales. Quality \& Quantity: International Journal of Methodology, v. 35, n. 3, p. 325-341, 2001.

VERGE, Tània. Party strategies on territorial reform: State-wide parties and the state of autonomies in Spain. West European Politics, v. 36, n. 2, p. 317-337, 2013. 
VON BEYME, Klaus. Right-wing extremism in post-war Europe. West European Politics, v. 11, n. 2, p. 531-532, 1988.

VOX. Programa electoral. 2019. Disponível em: <https://www.voxespana.es/espana/programaelectoral>. Acesso em: 20 nov. 2019.

ZULIANELLO, Mattia. Varieties of populist parties and party systems in Europe: Form state-of-theart to the application of a novel classification scheme to 66 parties in 33 countries. Government and Opposition, v. 55, n. 2, p. 327-347, 2019.

Texto recebido em 15 de janeiro de 2021. Aprovado em 03 de fevereiro de 2021. 
136 | Fabio Lupato, Leticia M. Rodríguez e Gema Medero

Anexo I

\begin{tabular}{|l|l|l|}
\hline Ano/ Estudo do CIS & Variável & Número pergunta \\
\hline $2015 / 3117$ & $\begin{array}{l}\text { localização própria } \\
\text { correspondências de localização } \\
\text { Eu me lembro da votação 2015 }\end{array}$ & $\begin{array}{l}\text { P21 } \\
\text { P2201 até P2217 } \\
\text { PP31* (*sic) }\end{array}$ \\
\hline $2016 / 3141$ & $\begin{array}{l}\text { localizaçáo própria } \\
\text { correspondências de localização } \\
\text { Eu me lembro da votação 2015 }\end{array}$ & P15 \\
& P1601 até P1616 \\
\hline $2017 / 3164$ & $\begin{array}{l}\text { localização própria } \\
\text { correspondências de localização } \\
\text { Eu me lembro da votação 2016 }\end{array}$ & $\begin{array}{l}\text { P2001 até P2016 } \\
\text { P23A }\end{array}$ \\
\hline $2018 / 3203$ & $\begin{array}{l}\text { localizaçáo própria } \\
\text { correspondências de localização } \\
\text { Eu me lembro da votação 2016 }\end{array}$ & $\begin{array}{l}\text { P18 } \\
\text { P1901 até P1916 } \\
\text { P22A }\end{array}$ \\
\hline $2019 / 3248:$ & $\begin{array}{l}\text { localizaçáo própria } \\
\text { correspondências de localização } \\
\text { Eu me lembro da votação 2019 }\end{array}$ & $\begin{array}{l}\text { P32 } \\
\text { P3301 até P3314 }\end{array}$ \\
\hline
\end{tabular}

Fonte: Elaboração própria. 


\section{Anexo II: Fórmulas utilizadas}

\begin{tabular}{|c|c|}
\hline $\begin{array}{l}\text { Sobreposição do } \\
\text { sistema partidário } \\
\text { e entre pares } \\
\text { partidários }\end{array}$ & $\begin{array}{l}\text { Índice de Sobreposição: } \\
\qquad S P_{A B}=1-\left(\sum_{k=1}^{5} \frac{\left|p_{k}^{x_{A}}-p_{k}^{x_{B}}\right|}{200}\right) \\
\text { Onde: } \\
\text { A e B são as duas partes a partir das quais a sobreposição é comparada. } \\
p_{k}^{x_{A}} \text { É a proporção de localizaçóes de eleitores do partido A na perna ideológica k e x } \\
\text { dividida por } 5 \text {. } \\
p_{k}^{x_{B}} \text { É a mesma proporção para eleitores do partido B no mesmo setor. } \\
\text { Fonte: Adaptado de Sani e Sartori (1983). }\end{array}$ \\
\hline $\begin{array}{l}\text { Especialização } \\
\text { ideológica }\end{array}$ & 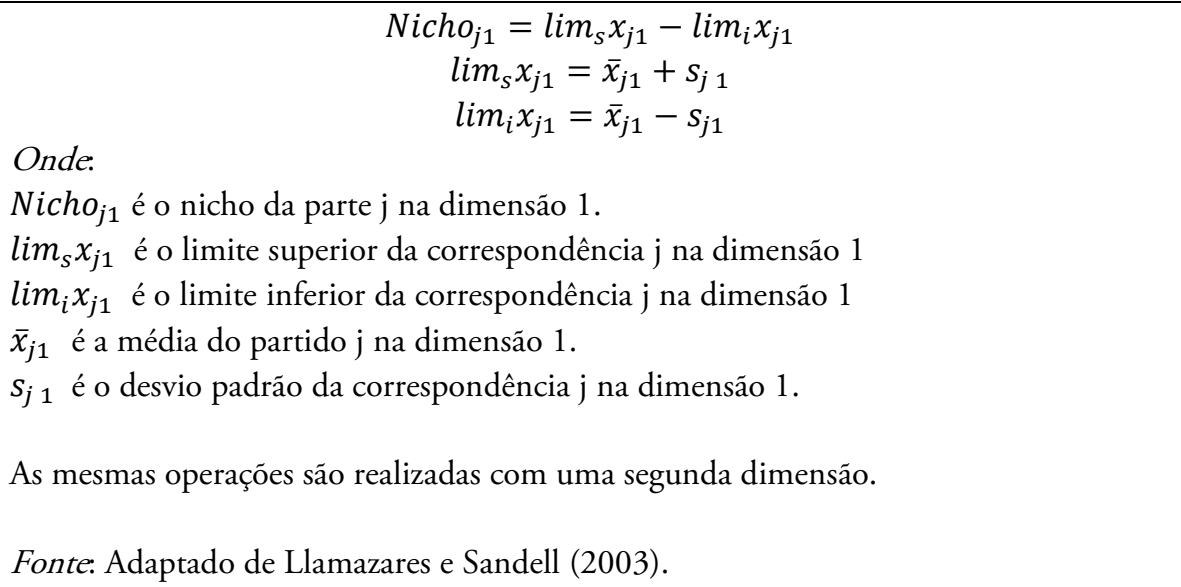 \\
\hline $\begin{array}{l}\text { Coerência } \\
\text { ideológica }\end{array}$ & $\begin{array}{l}\text { Coeficiente de concordância: } \\
\qquad \mathrm{A}=\left(1-\frac{(S-1)}{(k-1)}\right) \\
\text { Onde: S é o número de categorias não vazias e K é o número de categorias na escala } \\
\text { ideológica. } \\
\text { Fonte: adaptado de Van der Eijk (2001). }\end{array}$ \\
\hline
\end{tabular}

Fonte: Elaboração própria. 